Article

\title{
Antimicrobial Efficacy of Low Concentration PVP-Silver Nanoparticles Deposited on DBD Plasma-Treated Polyamide 6,6 Fabric
}

\author{
Ana Isabel Ribeiro ${ }^{1} \mathbb{1}$, Dilara Senturk ${ }^{1}$, Késia Karina Silva ${ }^{2}$, Martina Modic ${ }^{3}$, Uros Cvelbar ${ }^{3}$, \\ Gheorghe Dinescu ${ }^{4}\left(\mathbb{D}\right.$, Bogdana Mitu ${ }^{4}$, Anton Nikiforov ${ }^{5}$, Christophe Leys ${ }^{5}$, Irina Kuchakova ${ }^{5}$, \\ Mike De Vrieze ${ }^{6}$, António Pedro Souto ${ }^{1}$ and Andrea Zille ${ }^{1, *(\mathbb{D})}$ \\ 1 2C2T-Centro de Ciência e Tecnologia Têxtil, Universidade do Minho, Campus de Azurém, 4800-058 \\ Guimarães, Portugal; a.isabel.f.ribeiro@gmail.com (A.I.R.); senturkdilara764@gmail.com (D.S.); \\ souto@det.uminho.pt (A.P.S.) \\ 2 Department of Textile Engineering, Federal University of Rio Grande do Norte, Natal/RN 1524, Brazil; \\ kesiasouto@hotmail.com \\ 3 Jožef Stefan Institute, 1000 Ljubljana, Slovenia; Martina.Modic@ijs.si (M.M.); \\ uros.cvelbar@guest.arnes.si (U.C.) \\ 4 National Institute for Lasers, Plasma and Radiation Physics, 077125 Măgurele, Romania; \\ dinescug@infim.ro (G.D.); mitub@infim.ro (B.M.) \\ 5 Department of Applied Physics, Ghent University, 9000 Ghent, Belgium; Anton.Nikiforov@UGent.be (A.N.); \\ Christophe.Leys@UGent.be (C.L.); Iryna.Kuchakova@UGent.be (I.K.) \\ 6 Centexbel Ghent, Technologie park 7, 9052 Ghent, Belgium; Mike.DeVrieze@centexbel.be \\ * Correspondence: azille@2c2t.uminho.pt
}

Received: 1 August 2019; Accepted: 12 September 2019; Published: 14 September 2019

check for updates

\begin{abstract}
In this study, a low concentration $\left(10 \mu \mathrm{g} \cdot \mathrm{mL}^{-1}\right)$ of poly(N-vinylpyrrolidone) (PVP)-coated silver nanoparticles (AgNPs) were deposited by spray and exhaustion $\left(30,70\right.$ and $\left.100{ }^{\circ} \mathrm{C}\right)$ methods onto untreated and dielectric barrier discharge (DBD) plasma-treated polyamide 6,6 (PA66) fabric. DBD plasma-treated samples showed higher AgNP deposition than untreated ones for all methods. After five washing cycles, only DBD plasma-treated samples displayed AgNPs on the fabric surface. The best-performing method was exhaustion at $30^{\circ} \mathrm{C}$, which exhibited less agglomeration and the best antibacterial efficacy against $S$. aureus (4 $\mathrm{log}$ reduction). For E. coli, the antimicrobial effect showed good results in all the exhaustion samples (5 log reduction). Considering the spray method, only the DBD plasma-treated samples showed some bacteriostatic activity for both strains, but the AgNP concentration was not enough to have a bactericidal effect. Our results suggest DBD plasma may be a low cost and chemical-free method for the preparation of antibacterial textiles, allowing for the immobilization of a very low—but effective-concentration of AgNPs.
\end{abstract}

Keywords: silver nanoparticles; dielectric barrier discharge; plasma; antimicrobial; exhaustion; spray

\section{Introduction}

Progressive growth in antimicrobial resistance is leading to the rise of recalcitrant infections, complications of illness and mortality. Thus, there is great demand for the development of new antimicrobial agents and materials [1]. Silver ions display intrinsic antimicrobial, antiviral and anti-inflammatory properties and have been used-mostly in the form of silver salts-in medical textiles for wound dressings, surgical sutures and medical staff uniforms [2,3]. Recent developments in nanotechnology have created new advantages for silver-based antimicrobial textiles. The unique chemical and physical properties and high surface-volume ratio of silver nanoparticles (AgNPs) have 
made this new tool an extremely efficient antimicrobial agent [4-6]. The size, concentration and distribution of AgNPs onto textile substrates is fundamental to the balance and control of antimicrobial efficacy and cytotoxicity [7]. Indeed, AgNPs can be cytotoxic to human cells if small-sized nanoparticles (less than $15 \mathrm{~nm}$ ) and high concentrations are prescribed to patients [8]. Numerous techniques can be applied to deposit nanoparticles onto textiles, including aerosol, electrospray, convective assembly, sputtering, spin-coating, evaporation, dip-coating, exhaustion, impregnation, chemical vapor deposition and sonochemical immobilization $[9,10]$. However, most of obtained textiles possess AgNPs with weak adhesion, irregular distribution or a high degree of agglomeration [11]. AgNP capping agents, such as oleic acid, polyacrylic acid, polyethylene glycol (PEG), polyvinyl alcohol (PVA), and poly(N-vinylpyrrolidone) (PVP), are commonly used to prevent agglomeration during AgNP synthesis or dispersion preparation. Despite this, agglomeration can still occur during the deposition process onto textiles, even when capping agents are used [12,13].

One efficient strategy to avoid such drawbacks, enhance antimicrobial efficacy and reduce cytotoxicity can be the concomitant application of three conditions: (i) Decrease AgNP concentration, (ii) reduce agglomeration, and (iii) improve bonding between the AgNPs and textile substrates [11,14].

Double dielectric barrier plasma discharge techniques have been tested in the last years and revealed as a promising technique for textile coatings adhesion, including AgNPs [15]. Dielectric barrier discharge (DBD) plasma treatment is faster and more environmentally friendly than chemical surface modification techniques, which act exclusively on the material surface without affecting the bulk properties [16]. Moreover, when DBD plasma is operated in air, without the use of expensive carrier gases, this technique is very cost-effective [17]. Oxidation reactions during DBD plasma treatment in air generate polar functional groups that may improve the hydrophilicity of the material, creating highly reactive species on its surface [18]. Additionally, reactive oxygen species (ROS) and reactive nitrogen species (RNS) produced during DBD plasma treatment in air can also have antimicrobial action [19]. Plasma-assisted deposition of AgNPs also includes the formation of micro-roughness, which can enhance the adhesion and washing fastness of AgNPs [20].

In this study, polyamide 6,6 (PA66) fabric samples with and without DBD pre-treatment were coated with a low concentration of PVP-coated AgNPs by exhaustion (at 30, 70 and $100{ }^{\circ} \mathrm{C}$ ) and spray methods. This is the first time that a such low concentration of AgNPs was systematically studied for its potential in antimicrobial textile fabrics. The concentration of AgNPs on the PA66 surface was evaluated before and after five washing cycles. FTIR, reflectance spectroscopy, SEM and XPS techniques were performed in order to understand the nature of the interactions between the AgNPs and fabric surface. Antibacterial analyses were also performed against Gram-negative Escherichia coli and Gram-positive Staphylococcus aureus bacteria.

\section{Materials and Methods}

Commercial polyamide 6,6 fabric with a warp density of 50 threads $\cdot \mathrm{cm}^{-1}$, a weft density of 32 threads $\cdot \mathrm{cm}^{-1}$, and a weight per unit area of $110 \mathrm{~g} \cdot \mathrm{m}^{-2}$ was used. The fabric was firstly washed with $1 \mathrm{~g} \cdot \mathrm{L}^{-1}$ of a non-ionic detergent in water solution at $60{ }^{\circ} \mathrm{C}$ for $60 \mathrm{~min}$, rinsed with distilled water and then dried at $40^{\circ} \mathrm{C}$ to minimize contaminants. PVP AgNPs $(\sim 20 \mathrm{~nm})$ were acquired from Sigma-Aldrich (St. Louis, MO, USA) and used without purification.

The DBD plasma treatment was performed at atmospheric pressure and room temperature in a semi-industrial prototype machine (Softal GmbH/University of Minho, Guimarães, Portugal), using metal electrodes coated with ceramic and counter electrodes coated with silicon. The electrodes, with a $50 \mathrm{~cm}$ effective width and gap distance of $3 \mathrm{~mm}$, produced the discharge at low frequency $(40 \mathrm{kHz})$ and high voltage $(10 \mathrm{kV})$. The speed of the machine and discharge power of the electrodes could be modified, with a maximum speed of $60 \mathrm{~m} \cdot \mathrm{min}^{-1}$ and discharge of $1.5 \mathrm{~kW}$. In this study, the machine was operated at $1 \mathrm{~kW}$ of power and a velocity of $4 \mathrm{~m} \cdot \mathrm{min}^{-1}$, as these have been previously reported as the optimized conditions for PA66, corresponding to a dosage of $5 \mathrm{~kW} \mathrm{~min} \cdot \mathrm{m}^{-2}$ [17]. The estimated temperature of DBD atmospheric plasma in air is near to room temperature. However, 
taking into account a by-product reaction with air and treated polymers, a temperature up to $400 \mathrm{~K}$ can be attained [21,22].

The surface wettability of the untreated and plasma-treated fabrics was characterized with Dataphysics equipment using OCA20 software with a video system for capturing images in static mode.

PVP-AgNP dispersions $\left(10 \mu \mathrm{g} \cdot \mathrm{mL}^{-1}\right)$ in water were prepared using a Branson 3510 ultrasonic bath for $30 \mathrm{~min}$ and an Optic Ivymen System CY-500 ultrasonic tip for more than $30 \mathrm{~min}$. PVP-AgNPs were deposited in $5 \times 5 \mathrm{~cm}^{2}$ PA66 samples with and without DBD plasma pre-treatment. PVP-AgNP dispersions were applied by (i) spray on both sides, where the system was maintained at a distance of $5 \mathrm{~cm}$ from the substrate and pressurized at $1.5 \mathrm{bar}$, and by (ii) exhaustion in a laboratory-dyeing machine (Ahiba, Datacolor, Lawrenceville, NJ, USA) at 30, 70 and $100{ }^{\circ} \mathrm{C}$ for $60 \mathrm{~min}, 40 \mathrm{rpm}$ with a 1:100 ratio bath. All samples were dried at room temperature.

The washing fastness of PVP-AgNPs deposited onto PA66 samples was evaluated after five washing cycles in a laboratory-dyeing machine (Ahiba, Datacolor, Lawrenceville, NJ, USA) at $75^{\circ} \mathrm{C}$ and $40 \mathrm{rpm}$ for $15 \mathrm{~min}$ with $0.1 \mathrm{~g} \cdot \mathrm{L}^{-1}$ of a non-ionic surfactant in a liquor bath ratio of 1:30, according to EN ISO 15797 (industrial washing) [23].

A Shimadzu IRAffinity-1S FTIR spectrophotometer with an attenuated total reflectance (ATR, Preiser Scientific, Saint Albans, WV, USA) accessory equipped with a 1 reflection diamond crystal was used to record the FTIR-ATR spectra of the fabrics, performing 45 scans at a spectral resolution of $4 \mathrm{~cm}^{-1}$ over the range $400-4000 \mathrm{~cm}^{-1}$. Samples with and without DBD plasma treatment were analyzed.

The diffuse reflectance spectra of the untreated and plasma-treated PA66 fabrics with adsorbed PVP-AgNPs were obtained using a Spectraflash 600 (Datacolor, Lawrenceville, NJ, USA) spectrophotometer at standard illuminant D65 (LAV/Spec. Excl., d/8, D65/10 ${ }^{\circ}$. The reflectance data were presented as a percentage in the AgNPs maximum wavelength absorbance $(420 \mathrm{~nm})$. Untreated and DBD plasma-treated PA66 samples with and without AgNPs were evaluated in triplicate.

Morphological analyses of PA66 fabrics were performed with an ultra-high resolution field emission gun-scanning electron microscope (FEG-SEM; NOVA 200 Nano SEM, FEI Company, Hillsboro, OR, USA). The secondary electron images were carried out with an acceleration voltage at $5 \mathrm{kV}$, while the backscattering electron images were obtained with an acceleration voltage of $15 \mathrm{kV}$. A film of $\mathrm{Au}-\mathrm{Pd}(80-20 \mathrm{wt} \%)$ was used to coat the samples using a high-resolution sputter coater $(208 \mathrm{HR}$ Cressington Company, Watford, United Kingdom) coupled to an MTM-20 Cressington High Resolution Thickness Controller.

XPS analyses were carried out using a Kratos AXIS Ultra HSA (Kratos Analytical, Manchester, United Kingdom) with VISION software for data acquisition. The analysis was achieved using a monochromatic $\mathrm{Al} \mathrm{K} \alpha$ X-ray source $(1486.7 \mathrm{eV})$, which was operated at $15 \mathrm{kV}(150 \mathrm{~W})$ in FAT mode (Fixed Analyzer Transmission), with a pass energy of $40 \mathrm{eV}$ for the region of interest and $80 \mathrm{eV}$ for the survey spectra. The working pressure was maintained lower than $1 \times 10^{6} \mathrm{~Pa}$ and a charge neutralization system was used. The binding energy scale was adjusted according to the $\mathrm{C} 1 \mathrm{~s}$ spectral component at $285.9 \mathrm{eV}$. The high-resolution spectra were obtained considering an analysis area of $\approx 1 \mathrm{~mm}^{2}$. The full width at half maximum (FWHM) of the main peak was considered for the other peaks; this process introduced an associated error of $\pm 0.1 \mathrm{eV}$. The spectra analyses for elemental composition were performed with CASAXPS software (version 2.3.15). Deconvolutions were achieved by XPSPEAK (version 4.1) using the least squares method, which fit the data with the Gaussian/Lorentzian sum function after Shirley-type background subtraction. The tailing function was not considered during the fitting process.

The antibacterial efficacy of the PA66 samples was assessed according to the quantitative standard shake flask method (ASTM-E2149-01) [24]. Gram-positive Staphylococcus aureus (S. aureus, ATCC 6538) and Gram-negative Escherichia coli (E. coli, ATCC 25922) bacteria were used. Any contamination was prevented by conducting the experiment aseptically. Bacteria inoculum in tryptic soy broth (TSB, Merck) were processed from a single colony and incubated for $12 \mathrm{~h}$ at $37^{\circ} \mathrm{C}$ and $120 \mathrm{rpm}$. An initial concentration of 1.5-3.0 $\times 10^{7} \mathrm{CFUs} / \mathrm{mL}$ in PBS was used. PA66 fabrics (0.05 g weight) were incubated 
in $5 \mathrm{~mL}$ of bacteria suspension for $24 \mathrm{~h}$ at $37^{\circ} \mathrm{C}$ and $100 \mathrm{rpm}$. Before $(0 \mathrm{~h})$ and after the contact with samples $(24 \mathrm{~h}$ ), the bacteria were serially diluted and cultured onto tryptic soy agar (TSA, Merck) plates, and incubated for more than $24 \mathrm{~h}$. After this period, the colonies of surviving bacteria on the agar plates were counted. Antimicrobial activity was presented as a log reduction, calculated as the ratio between the number of surviving bacteria colonies, before and after contact with the samples. All antimicrobial tests were performed in triplicate.

\section{Results}

\subsection{FTIR-ATR Analyses of Untreated and Plasma-Treated PA66 Samples}

As shown in Figure 1, the FTIR spectra of untreated and DBD plasma-treated PA66 possess the typical bands of polyamide at 3290, 2931 and $2858 \mathrm{~cm}^{-1}$, attributable to $\mathrm{NH}_{2}$ stretching, $\mathrm{CH}_{2}$ asymmetric, and symmetric stretching vibrations, respectively. The strong intensity peaks of amide carbonyl N-C=O (amide I) and N-H bending from amide II are exhibited at $1630 \mathrm{~cm}^{-1}$ and $1530 \mathrm{~cm}^{-1}$. The band at $680 \mathrm{~cm}^{-1}$ represents the bending of the $\mathrm{O}=\mathrm{C}-\mathrm{N}$ group. A particularity of the samples with plasma treatment is the presence of a new weak band at $1728 \mathrm{~cm}^{-1}$. This band may be attributed to the $\mathrm{C}=\mathrm{O}$ stretching of ketones, aldehydes and carboxylic acids, formed by reactive oxygen species during plasma discharge $[25,26]$. Moreover, after plasma treatment, some change can be noted in the characteristic crystalline peaks of PA66 at $930 \mathrm{~cm}^{-1}$ and $1200 \mathrm{~cm}^{-1}$, attributable to the amide axial deformation $(\mathrm{C}-\mathrm{C}=\mathrm{O})$ and symmetrical angular deformation of out of plane amide III, respectively.



Figure 1. FTIR-attenuated total reflectance (ATR) spectra of polyamide 6,6 (PA66) fabric with plasma treatment (solid line) and without plasma treatment (dashed line).

\subsection{Reflectance Spectroscopy}

AgNPs of $20 \mathrm{~nm}$ are known to have the highest absorption in the visible region around $420 \mathrm{~nm}$. Thus, this wavelength was considered for AgNP detection (Figure 2). The PA66 samples obtained by spray and exhaustion methods at different temperatures were analyzed before and after five washing cycles.

For the unwashed samples, the spray deposition method showed the lowest AgNP deposition rate with no significant difference between the untreated and plasma-treated samples (Figure 2a). On the other hand, the exhaustion methods demonstrated superior AgNP loading, especially at $100{ }^{\circ} \mathrm{C}$, 
well above the glass transition temperature of PA66. At $70{ }^{\circ} \mathrm{C}$ and $100{ }^{\circ} \mathrm{C}$, only a slight difference between samples with and without DBD plasma treatment was observed. The deposition method by exhaustion at $30{ }^{\circ} \mathrm{C}$ of the untreated sample showed, as expected, a very low deposition yield, exhibiting a high value of reflectance $(75 \%)$. However, after DBD plasma treatment, the reflectance value was comparable with the values obtained at $70^{\circ} \mathrm{C}$ and $100^{\circ} \mathrm{C}$ with and without plasma treatment.

The washing fastness of the AgNPs deposited onto the PA66 samples was evaluated after five consecutive cycles of industrial laundries at $75^{\circ} \mathrm{C}$ for $15 \mathrm{~min}$ (Figure 2b). Comparing the different AgNP deposition methods and plasma treatment effects after laundering, a superior washing resistance of the loaded AgNPs in the plasma-treated samples was observed. Also in this case, the best result was observed for the exhaustion method at $30^{\circ} \mathrm{C}$ on the DBD plasma-treated samples.



(a)

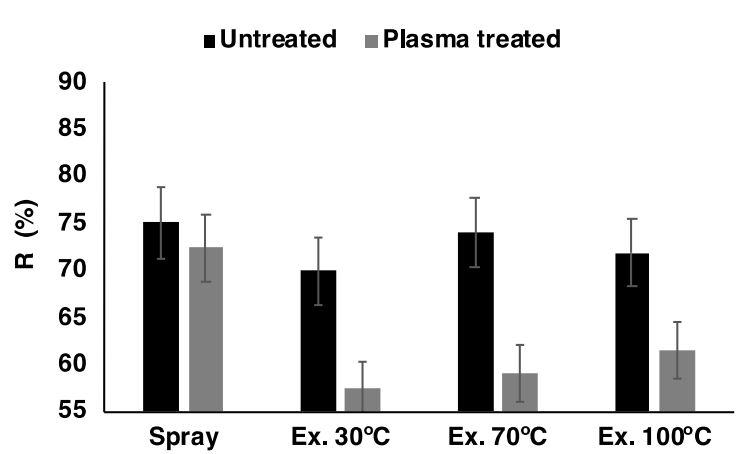

(b)

Figure 2. Diffuse reflectance (\%) at $420 \mathrm{~nm}$ for the untreated and dielectric barrier discharge (DBD) plasma-treated samples with poly(N-vinylpyrrolidone)-coated silver nanoparticles (PVP-AgNPs) before washing (a) and after five washing cycles (b).

\subsection{SEM and EDS Analysis}

SEM images were captured to evaluate the deposition efficiency and distribution of the AgNPs on the untreated and DBD plasma-treated PA66 samples obtained with the two different deposition methods (Figure 3). DBD plasma-treated samples displayed an increased surface roughness, as reported previously [26]. Considering the different deposition methods, the exhaustion samples presented a higher AgNP concentration when compared with the spray samples. The exhaustion methods showed superior AgNP deposition when the temperature was raised from 30 to $70{ }^{\circ} \mathrm{C}$, but more agglomeration was also observed.

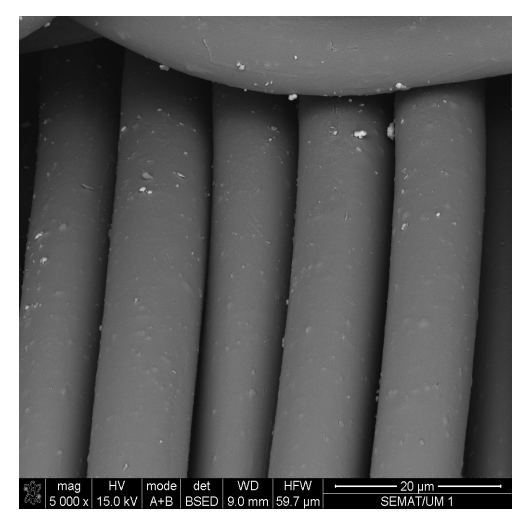

(a)

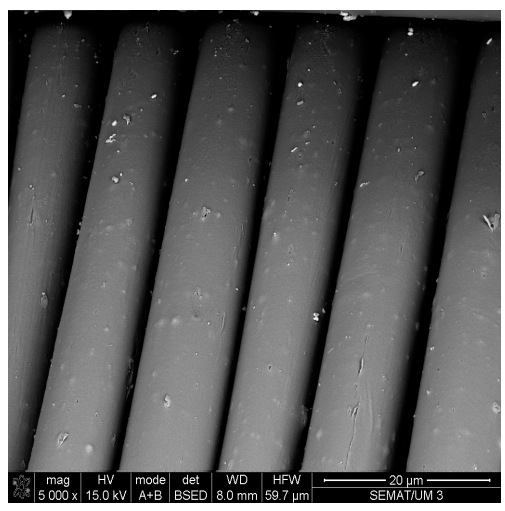

(b)

Figure 3. Cont. 


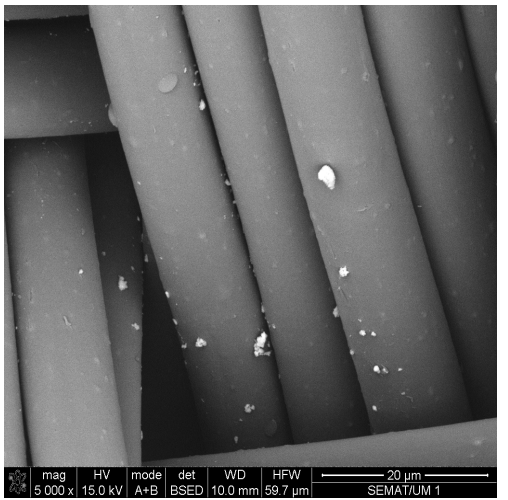

(c)

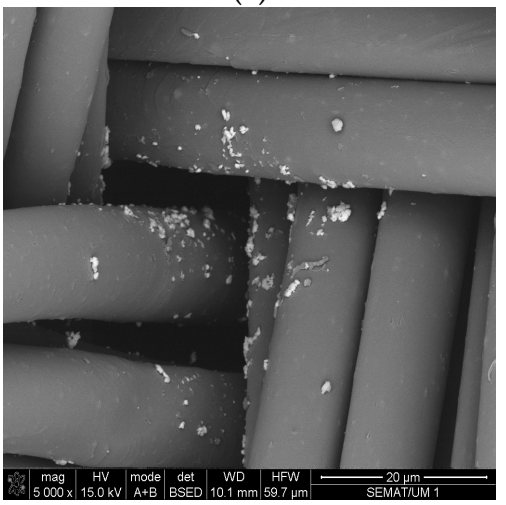

(e)

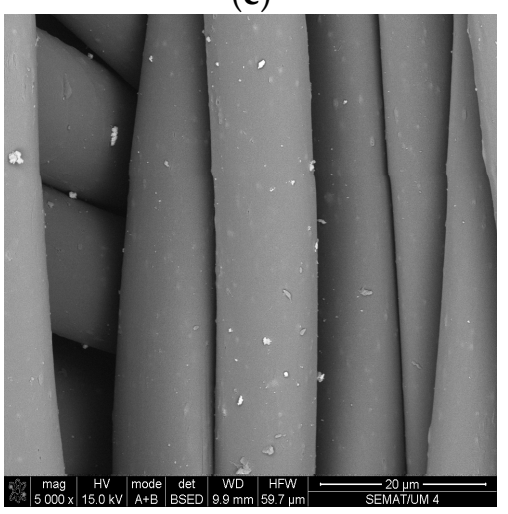

(g)

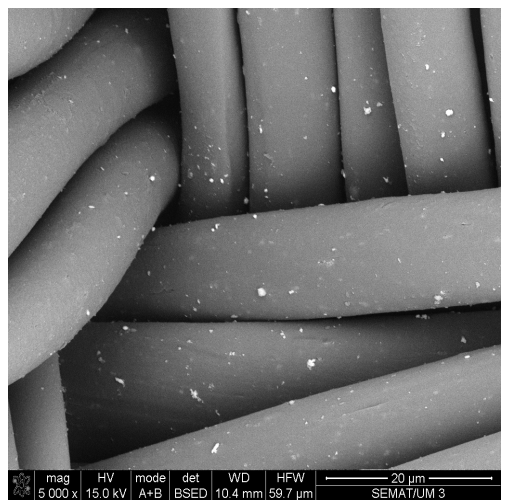

(d)

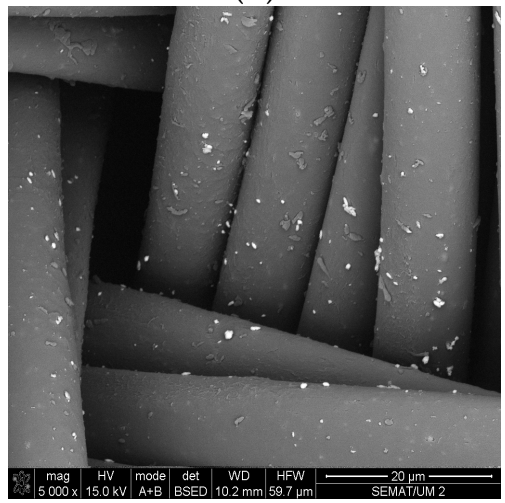

(f)

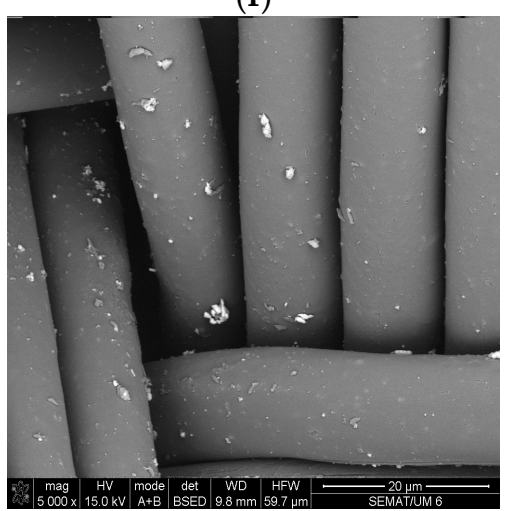

(h)

Figure 3. SEM images of untreated $(\mathbf{a}, \mathbf{c}, \mathbf{e}, \mathbf{g})$ and DBD plasma-treated $(\mathbf{b}, \mathbf{d}, \mathbf{f}, \mathbf{h})$ PA66 samples with AgNPs deposited by spray $(\mathbf{a}, \mathbf{b})$, exhaustion at $30{ }^{\circ} \mathrm{C}(\mathbf{c}, \mathbf{d})$, exhaustion at $70{ }^{\circ} \mathrm{C}(\mathbf{e}, \mathbf{f})$ and exhaustion at $100{ }^{\circ} \mathrm{C}(\mathbf{g}, \mathbf{h})$, with a magnification of $5000 \times$.

Peaks associated with silver were detected on the surface of both spray and exhaustion samples by EDS analysis (Figure 4). The characteristic peaks of silver (AgLI, AgLa, AgLb and AgLg) were observed in the EDS spectrum between 2.5 and $3.4 \mathrm{KeV}$. An Au peak, derived from the coating process prior to analysis, was also observed. Carbon and oxygen peaks were also detected, corresponding to the PA66 atomic components. 


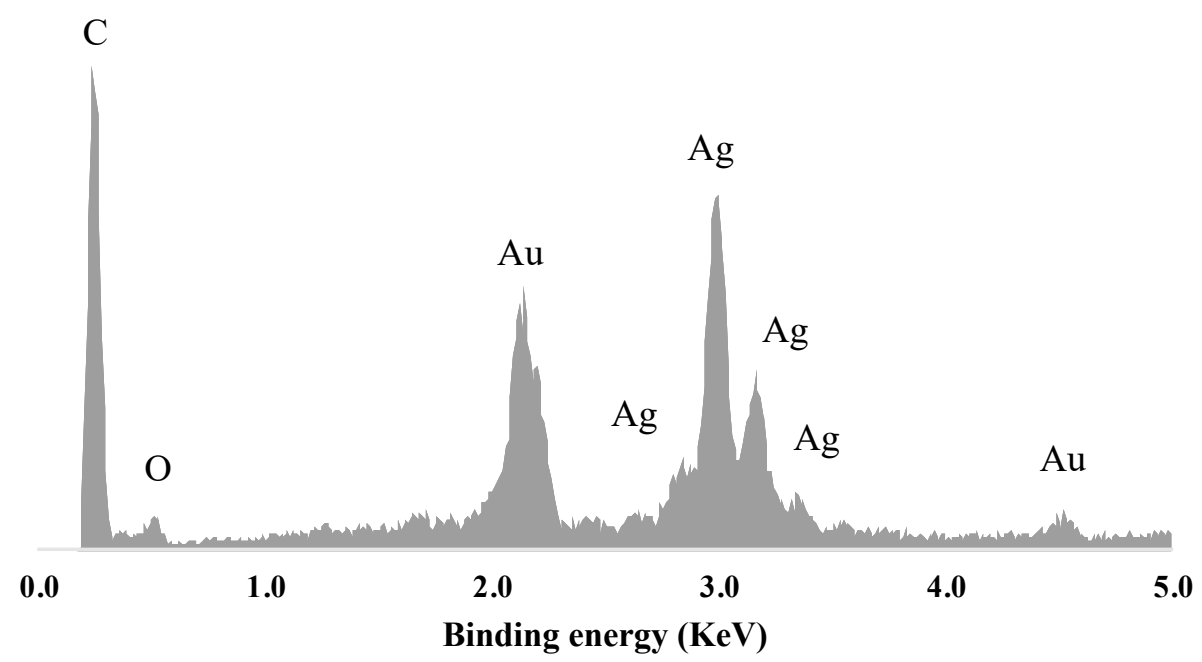

(a)

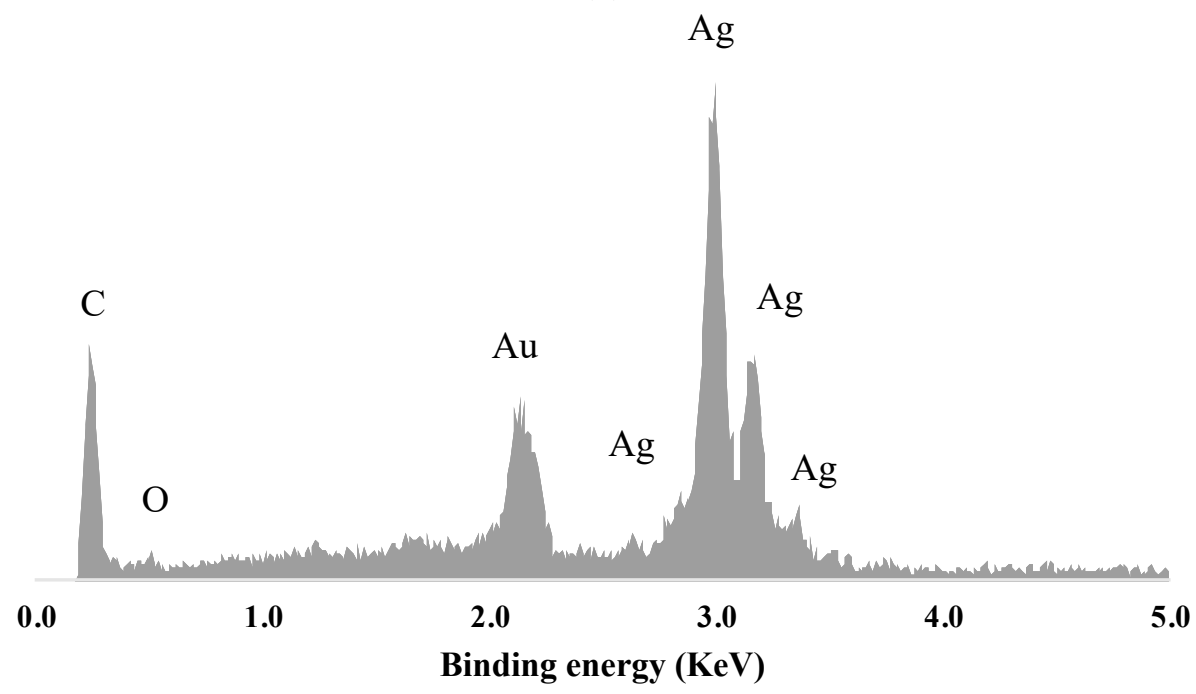

(b)

Figure 4. EDS analysis of the spray (a) and exhaustion at $30^{\circ} \mathrm{C}(\mathbf{b})$ deposition methods for the PA66 samples with DBD plasma treatment.

\subsection{XPS Analysis}

The results from the XPS spectra analysis were used to calculate the relative chemical composition and atomic ratios $(\mathrm{O} / \mathrm{C}$ and $\mathrm{N} / \mathrm{C})$ of the untreated and DBD plasma-treated samples with AgNPs deposited by spray and exhaustion (at $30^{\circ} \mathrm{C}$ and $70{ }^{\circ} \mathrm{C}$ ) (Table 1 ). The relative chemical compositions showed an increase in oxygen content, higher atomic $\mathrm{O} / \mathrm{C}$ and lower $\mathrm{N} / \mathrm{C}$ ratios compared to the control samples without DBD plasma treatment. Silver was only detected in the DBD plasma-treated samples in exhaustion conditions $\left(1.5\right.$ at $\%$ and 0.3 at $\%$ for the samples treated at $30{ }^{\circ} \mathrm{C}$ and $70{ }^{\circ} \mathrm{C}$, respectively). Chemical bonding information was achieved by deconvolution of $\mathrm{C} 1 \mathrm{~s}, \mathrm{~N} 1 \mathrm{~s}$ and $\mathrm{O} 1 \mathrm{~s}$ for all the tested samples and Ag3d for the DBD plasma-treated samples obtained by exhaustion at $30^{\circ} \mathrm{C}$ and $70{ }^{\circ} \mathrm{C}$ (Table 2 and Figure 5). The $\mathrm{C} 1 \mathrm{~s}$ spectra showed three peaks between 285.0 and $288.0 \mathrm{eV}$. A major peak appearing at $285.0 \mathrm{eV}$ was attributed to $\mathrm{C}-\mathrm{C}$ and $\mathrm{C}-\mathrm{H}$ bonds. A peak assigned to $\mathrm{C}-\mathrm{N}$ bonds emerged at $286.1 \mathrm{eV}$ for the untreated samples and $286.4 \mathrm{eV}$ for the plasma-treated samples. A C1s peak attributed to $\mathrm{O}=\mathrm{C}-\mathrm{N}$ also presented a positive shift in binding energy between samples with and without plasma treatment, but only for the exhaustion samples. The untreated and DBD plasma-treated spray samples, as well as the untreated exhaustion samples, showed an $\mathrm{O}=\mathrm{C}-\mathrm{N}$ peak at $287.8 \mathrm{eV}$. In the exhaustion DBD plasma-treated samples, the same peak appeared at $288.0 \mathrm{eV}$. The O1s 
high resolution spectra presented two peaks, attributed to $\mathrm{O}=\mathrm{C}$ and $\mathrm{O}-\mathrm{C}$. The $\mathrm{O}=\mathrm{C}$ bonds emerged at $531.2 \mathrm{eV}$ for the untreated samples and $531.4 \mathrm{eV}$ for the plasma-treated samples, while the $\mathrm{O}-\mathrm{C}$ bonds emerged at $532.9 \mathrm{eV}$ for all the samples [27]. The N1s spectra showed two peaks at 399.7 and $401.6 \mathrm{eV}$, which were attributed to $\mathrm{O}=\mathrm{C}-\mathrm{N}$ due to the asymmetrical bonds dependent on the silver content [26]. The results of the Ag3d deconvolution analysis showed two peaks at 367.8 and $374.6 \mathrm{eV}$.

Table 1. Relative chemical compositions and atomic ratios of untreated and DBD plasma-treated PA66 fabrics with AgNPs deposited with spray and exhaustion at $30^{\circ} \mathrm{C}$ and $70{ }^{\circ} \mathrm{C}$ methods.

\begin{tabular}{ccccccc}
\hline Samples & C (at \%) & O (at \%) & N (at \%) & Ag (at \%) & O/C Ratio & N/C Ratio \\
\hline Spray & 80.5 & 11.0 & 8.5 & ND & 0.14 & 0.11 \\
Spray DBD & 79.5 & 13.0 & 7.5 & ND & 0.16 & 0.09 \\
Ex. 30 & 77.9 & 11.8 & 10.3 & ND & 0.15 & 0.13 \\
Ex. 30 DBD & 77.0 & 12.5 & 9.0 & 1.5 & 0.16 & 0.12 \\
Ex. 70 & 80.1 & 11.0 & 8.9 & ND & 0.14 & 0.11 \\
Ex. 70 DBD & 79.9 & 11.6 & 8.2 & 0.3 & 0.15 & 0.10 \\
\hline
\end{tabular}

Table 2. Results of the deconvolution analysis of the $\mathrm{C} 1 \mathrm{~s}, \mathrm{~N} 1 \mathrm{~s}, \mathrm{O} 1 \mathrm{~s}$ and $\mathrm{Ag} 3 \mathrm{~d}$ peaks for the untreated and DBD plasma-treated PA66 fabrics with AgNPs deposited with spray and exhaustion at $30{ }^{\circ} \mathrm{C}$ and $70{ }^{\circ} \mathrm{C}$ methods. Reported binding energies have an associated error of $\pm 0.1 \mathrm{eV}$.

\begin{tabular}{|c|c|c|c|c|c|c|c|c|c|c|c|c|}
\hline \multirow{2}{*}{ Samples } & \multicolumn{2}{|c|}{$\operatorname{Ag} 3 d$} & \multicolumn{5}{|c|}{$\mathrm{C} 1 \mathrm{~s}$} & \multicolumn{3}{|c|}{ O1s } & \multicolumn{2}{|c|}{ N1s } \\
\hline & $\begin{array}{c}367.8 \\
\mathrm{eV}\end{array}$ & $\begin{array}{c}374.6 \\
\mathrm{eV}\end{array}$ & $\begin{array}{c}285.0 \\
\mathrm{eV}\end{array}$ & $\begin{array}{c}286.1 \\
\mathrm{eV}\end{array}$ & $\begin{array}{c}286.4 \\
\mathrm{eV}\end{array}$ & $\begin{array}{c}287.8 \\
\mathrm{eV}\end{array}$ & $\begin{array}{c}288.0 \\
\mathrm{eV}\end{array}$ & $\begin{array}{c}531.2 \\
\mathrm{eV}\end{array}$ & $\begin{array}{c}531.4 \\
\mathrm{eV}\end{array}$ & $\begin{array}{c}532.9 \\
\mathrm{eV}\end{array}$ & $\begin{array}{c}399.7 \\
\mathrm{eV}\end{array}$ & $\begin{array}{c}401.6 \\
\mathrm{eV}\end{array}$ \\
\hline Spray No DBD & - & - & 71.5 & 13.4 & - & 15.0 & - & 74.3 & - & 25.7 & 95.6 & 4.4 \\
\hline Spray DBD & - & - & 67.6 & - & 16.9 & 15.5 & - & - & 55.9 & 44.1 & 91.4 & 8.6 \\
\hline Ex. 30 No DBD & - & - & 70.0 & 15.1 & - & 14.9 & - & 73.6 & - & 26.3 & 93.3 & 6.7 \\
\hline Ex. $30 \mathrm{DBD}$ & 52.2 & 47.8 & 67.2 & - & 16.5 & - & 16.3 & - & 71.4 & 28.6 & 93.4 & 6.6 \\
\hline Ex. 70 No DBD & - & - & 71.4 & 13.5 & - & 15.1 & - & 73.9 & - & 26.1 & 88.9 & 11.1 \\
\hline Ex. $70 \mathrm{DBD}$ & 57.7 & 42.3 & 68.9 & - & 15.4 & - & 15.7 & - & 71.7 & 28.3 & 89.5 & 10.5 \\
\hline
\end{tabular}
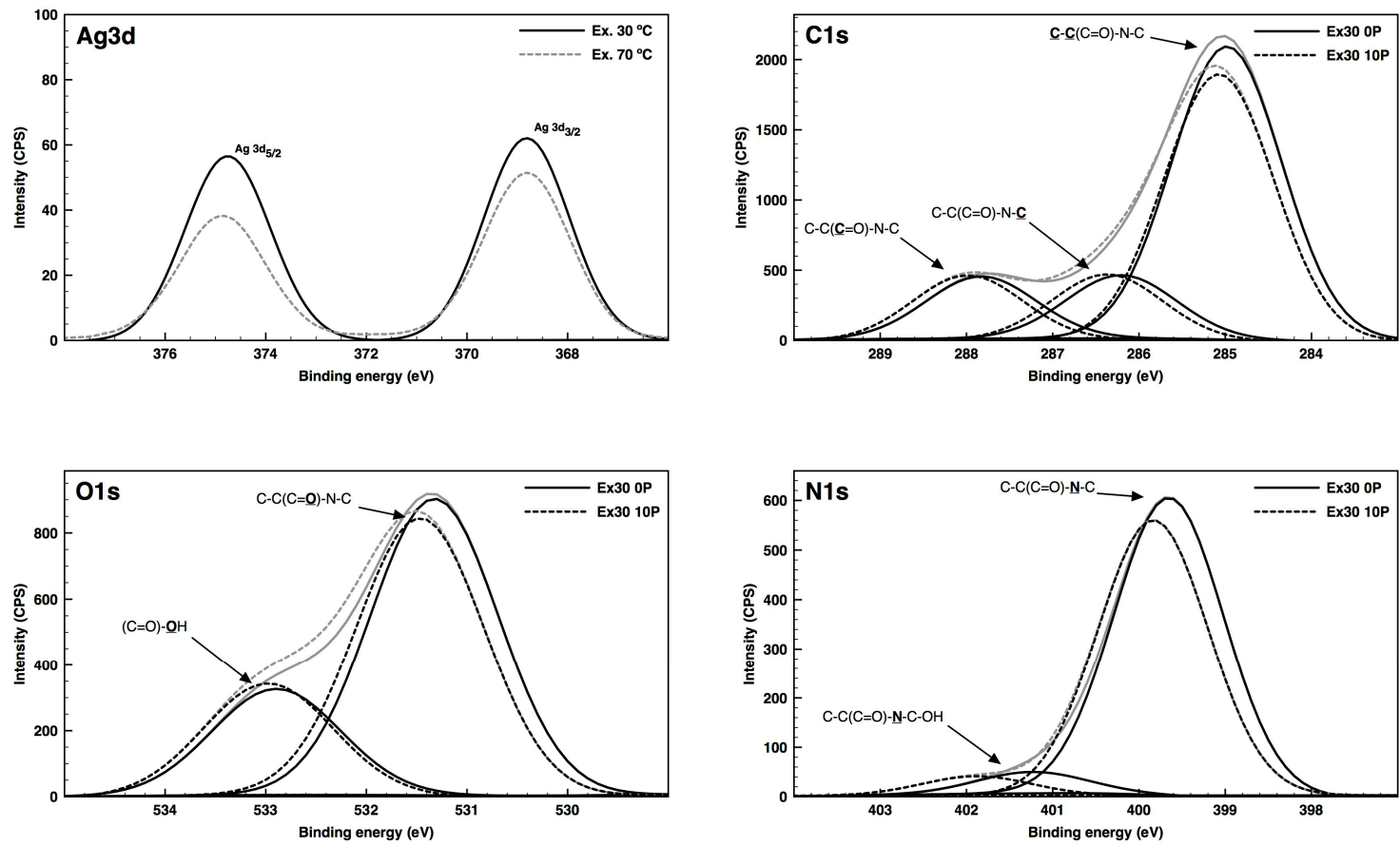

Figure 5. High-resolution deconvoluted XPS spectra with relative areas of the Ag3d, C1s, O1s and N1s binding energy regions of untreated and plasma-treated PA66 fibers surface with AgNPs deposited with the exhaustion method at $30^{\circ} \mathrm{C}$. 


\subsection{Antibacterial Activity}

Quantitative analysis of antibacterial efficiency of PA66 samples with a low concentration of AgNPs was performed against Gram-positive S. aureus and Gram-negative E. coli bacteria (Figure 6). Generally, the antibacterial efficacy toward E. coli was higher than toward S. aureus. For S. aureus, the DBD plasma-treated samples always presented an improved antibacterial performance. The exhaustion methods displayed higher antimicrobial activity than the spray method. The best performance was achieved by the exhaustion at $30^{\circ} \mathrm{C}$ method with DBD plasma treatment. This sample represented a $99.99 \%$ reduction (4 log reduction), with an effective antimicrobial effect. The spray method displayed only weak antibacterial activity for E. coli, while samples obtained by the exhaustion method showed complete inhibition (5 log reduction) for both untreated and DBD plasma-treated samples.

In order to confirm the superior immobilization ability of the AgNPs on the plasma-treated samples, the samples were tested for antimicrobial activity after five washing cycles (data not shown). The results showed that the plasma-treated sample obtained from the exhaustion at $30^{\circ} \mathrm{C}$ method was able to maintain reasonable antimicrobial activity despite the very low Ag concentration on the fabric surface (E. coli $\log$ reduction $1.94 \pm 0.01$ and S. aureus $\log$ reduction $0.34 \pm 0.02$ ). All other samples (spray and exhaustion at 70 and $100{ }^{\circ} \mathrm{C}$ with and without plasma treatment) did not display antimicrobial activity after washing.

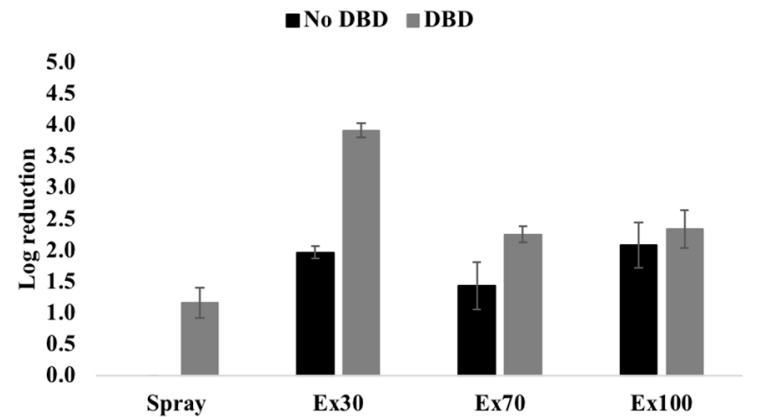

(a)

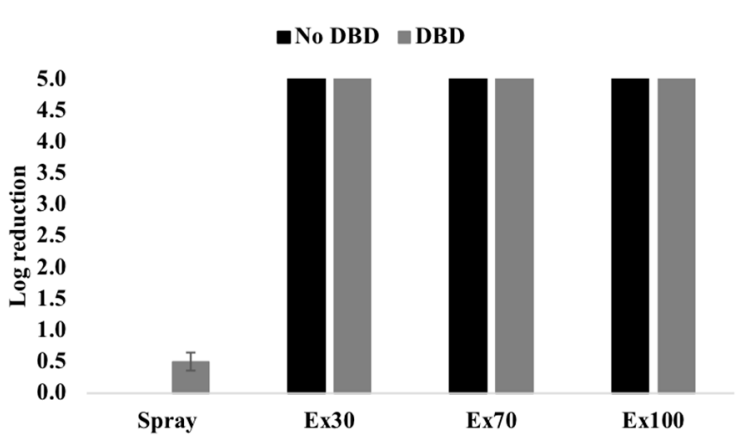

(b)

Figure 6. S. aureus (a) and E. coli (b) reduction of the untreated and DBD-plasma-treated samples with PVP-AgNPs after $24 \mathrm{~h}$ of contact.

\section{Discussion}

In order to improve AgNP adhesion onto a PA66 fabric surface, DBD plasma treatment was performed. The plasma treatment successfully modified the surface energy of the samples, as proved by the wettability results. The contact angle decreased from $90^{\circ} \pm 1.6^{\circ}$ to $40^{\circ} \pm 2.5^{\circ}$ after 5 passages and it was not detectable after 10 passages. DBD plasma discharge using atmospheric air and working with energies lower than $10 \mathrm{eV}$ could easily cause the breaking of the weakest bond in the polymer chain of PA66-the C-N bond-thereby creating new carbonyl groups, as proved in the FTIR spectra in Figure 1 [28]. Additionally, modification of the crystalline peaks of PA66 suggested alterations in its crystallinity and on the aliphatic polyamide structure [29]. No new peaks appeared in the FTIR spectra after deposition of AgNPs, suggesting the non-covalent nature of the interaction between AgNPs and the polyamide surface species. FTIR is not able to detect ionic, hydrogen (only detected as a shift or broadening of peaks), Van der Waals or electrostatic forces, which are forces that can significantly influence the physico-chemical adhesion of the silver nanoparticles. Moreover, a high-depth FTIR probe is not compatible with surface analyses. Thus, X-ray photoelectric and diffuse reflectance spectroscopy were employed to further investigate the AgNP deposition on the fabric surface.

Since AgNPs are able to absorb light in the visible region, diffuse reflectance spectroscopy measurements were performed on untreated and DBD plasma-treated PA66 samples in order to compare the relative amount of AgNPs on the fabric surface [7,30]. As a consequence of the low nanoparticle concentration used in this work, the main drawback of the spray method was that 
the AgNPs were only deposited on the very surface of the fabric without any significant volume deposition. This is because there are no mass transfer phenomena that can improve AgNP absorption into a fabric's bulk before washing, thereby justifying the lowest deposition rate observed in the spray method samples [31]. In the 70 and $100{ }^{\circ} \mathrm{C}$ exhaustion methods, the main factor for the higher AgNP deposition observed is the greater availability of the PA66 amorphous regions and enhanced mass transfer processes [32]. However, in the $30^{\circ} \mathrm{C}$ exhaustion method, the availability of the amorphous regions decrease, and the DBD plasma treatment effect is well noticed. Overall, DBD plasma treatment using the exhaustion method appeared to improve the adhesion of the AgNPs on the PA66 fabric, obtaining very good results at room temperature well below the glass transition temperature of the material. This is proved by the SEM/EDS analysis (Figures 3 and 4), which clearly showed an improved adhesion of the silver to PA66 samples. The EDS of exhaustion at $30^{\circ} \mathrm{C}$ (Figure $4 \mathrm{~b}$ ) displayed a silver peak double the size of the spray method (Figure 4a). The SEM analysis was also used to calculate the dimension of the deposited nanoparticles. The observed average dimension was about $100 \mathrm{~nm}$ for the spray and $30^{\circ} \mathrm{C}$ exhaustion methods; however, with an increase in the deposition temperature, larger agglomeration clusters (up to $1 \mu \mathrm{m}$ ) were detected. After washing, the reflectance results of the AgNPs on the fabric surface showed an apparent higher concentration of nanoparticles. This was due to the different reflectivity of the oxidized AgNPs deposited on the fabric surface, caused by the harsh washing conditions. However, the best results were obtained from the DBD plasma-treated sample with exhaustion deposition at $30^{\circ} \mathrm{C}$. The DBD plasma treatment allowed for a decrease in the deposition temperature, thereby improving the fixation of the AgNPs to the PA66 fabric. This was due to the enhanced roughness and plasma-generated polar groups on the PA66 fabric's surface [33,34]. Above the PA66 glass transition temperature, AgNPs are able to enhance their volume deposition in the bulk of the fabric by different deposition mechanisms. Thus, in this particular case, the samples treated at high temperatures $\left(70{ }^{\circ} \mathrm{C}\right.$ and $\left.100^{\circ} \mathrm{C}\right)$ were able to adsorb AgNPs on their fiber surface as much as the DBD plasma-treated sample. This is a consequence of the improved mass transport provided by the rubber-like structure of PA66 above its glass transition temperature and also by the higher kinetic energy of the system at a higher temperature [35].

The superior oxygen content in the DBD plasma-treated samples detected during XPS analysis confirmed the ability of plasma to incorporate oxygen atoms onto the fabric surface. Plasma activation and etching provoke scission of the $\mathrm{C}-\mathrm{H}, \mathrm{C}-\mathrm{O}, \mathrm{C}-\mathrm{N}, \mathrm{C}-\mathrm{C}$, and $\mathrm{N}-\mathrm{H}$ bonds of the fibers, promoting the addition and formation of reactive $\mathrm{O}^{-}, \mathrm{N}, \mathrm{N}^{+}, \mathrm{O}, \mathrm{OH}^{-}$, and $\mathrm{O}_{3}$ species on the fabric surface [36-38]. Silver was detected in XPS only in the DBD plasma-treated samples obtained by exhaustion, confirming the plasma-induced enhanced absorption of $\mathrm{Ag}$ at low temperatures. In both the plasma-treated and untreated spray samples, and in the untreated samples of the exhaustion methods, no Ag was detected because it was under the detection limit of the XPS equipment (0.1 at \%). The amount of silver detected in the high-temperature exhaustion deposition method $\left(70{ }^{\circ} \mathrm{C}\right)$ was lower than the $30^{\circ} \mathrm{C}$ method. This phenomena can be attributed to the morphological and chemical changes which occur in the nanoparticle structure due to a temperature-induced aging process, based on a combination of the coalescence and oxidation of the AgNPs, in addition to the thermodynamically-driven spontaneous process called Ostwald ripening [39,40]. The AgNPs deposited on the plasma-treated PA66 fabric showed a negative shift in binding energy for $\mathrm{Ag} 3 d_{5 / 2}(367.8 \mathrm{eV})$ relative to the bulk $\mathrm{Ag}(368.3 \mathrm{eV})$, indicating the presence of $\mathrm{Ag}^{+}$on the surface of the nanoparticles. Several studies correlate a negative shift in the binding energy of Ag3d peaks to an increase in the oxidation state of silver [41,42]. The presence of a negative shift in the Ag component, in combination with the increased binding energy of the double-bond oxygen species in the O1s deconvoluted spectra of the plasma-treated samples, indicates an interaction between the $\mathrm{Ag}^{+}$and plasma-generated oxygen species on the fabric surface [43].

The superior antimicrobial efficacy of AgNPs in E. coli compared to S. aureus may be attributed to the different cell wall structure and composition of the bacteria [35]. The peptidoglycan layer of Gram-positive bacteria is approximately ten times larger than that of Gram-negative bacteria, 
complicating the diffusion of Ag ions to the interior of the cell. Moreover, it has been reported that a strong interaction between the negatively-charged compounds in the cell wall of Gram-negative bacteria and AgNPs can act as a sequester of free silver ions, reducing their activity [44]. For S. aureus, the improved antimicrobial effect of DBD plasma-treated samples can be justified by the increased amount of immobilized AgNPs, promoted by the improved surface roughness of the fibers, and by the greater interaction between the AgNPs and new plasma-generated polar groups, as proved by the XPS analysis.

The successful use of such a low amount of AgNPs as an antimicrobial agent in plasma-treated polyamide fabric will allow for the controlled release of AgNPs in the environment and will reduce the health risk associated with the use of silver in humans. Most commercial antimicrobial fabrics are loaded with higher amounts of silver nanoparticles than the fabric developed in this study $[45,46]$.

\section{Conclusions}

In this study, DBD plasma treatment was shown to decrease the deposition temperature and improve the fixation of AgNPs at a low concentration onto PA66 fabric surfaces while providing a significant antimicrobial effect. A significant antimicrobial efficacy of DBD plasma-treated samples in E. coli and S. aureus was observed even after five washing cycles. The improved antimicrobial effect of the DBD plasma-treated samples with the exhaustion method compared to the spray method can be justified by: (i) The higher mass-transport effect provided by the excellent ratio of volume to surface area, (ii) the superior surface roughness of the fibers, and (iii) the higher interaction between the AgNPs and the plasma-generated oxygen species.

Author Contributions: A.I.R. wrote the manuscript, performed the main analysis and data collection. D.S. and K.K.S. performed data interpretation, M.M. and U.C. performed and interpreted the antimicrobial analysis, G.D., M.V. and B.M. supervised and performed data interpretation, A.N., C.L. and I.K. performed the XPS data analysis and deconvolutions. A.P.S. finalize the paper and data interpretation. A.Z. supervise all works and finalize the manuscript.

Funding: This work was funded by European Regional Development funds (FEDER) through the Competitiveness and Internationalization Operational Program (POCI)-COMPETE and by National Funds through Fundação para a Ciência e Tecnologia (FCT).

Acknowledgments: This work was funded by European Regional Development funds (FEDER) through the Competitiveness and Internationalization Operational Program (POCI) - COMPETE and by National Funds through Fundação para a Ciência e Tecnologia (FCT) - under the project POCI-01-0145-FEDER-007136 and UID/CTM/00264/2019. Isabel Ribeiro (SFRH/BD/137668/2018) acknowledges FCT, Portugal, for its doctoral grant financial support. A. Zille also acknowledges financial support of the FCT through an Investigator FCT Research contract (IF/00071/2015) and the project PTDC/CTM-TEX/28295/2017 financed by FCT, FEDER and POCI in the frame of the Portugal 2020 program.

Conflicts of Interest: The authors declare no conflict of interest.

\section{References}

1. Surwade, P.; Ghildyal, C.; Weikel, C.; Luxton, T.; Peloquin, D.; Fan, X.; Shah, V. Augmented antibacterial activity of ampicillin with silver nanoparticles against methicillin-resistant Staphylococcus aureus (MRSA). J. Antibiot. 2018, 72, 50-53. [CrossRef] [PubMed]

2. Ping, Y.; Zhang, J.; Xing, T.; Chen, G.; Tao, R.; Choo, K.-H. Green synthesis of silver nanoparticles using grape seed extract and their application for reductive catalysis of direct orange 26. J. Ind. Eng. Chem. 2018, 58, 74-79. [CrossRef]

3. Ajitha, B.; Reddy, Y.A.K.; Jeon, H.-J.; Ahn, C.W. Synthesis of silver nanoparticles in an eco-friendly way using phyllanthus amarus leaf extract: Antimicrobial and catalytic activity. Adv. Powder Technol. 2018, 29, 86-93. [CrossRef]

4. Vidanapathirana, A.K.; Thompson, L.C.; Herco, M.; Odom, J.; Sumner, S.J.; Fennell, T.R.; Brown, J.M.; Wingard, C.J. Acute intravenous exposure to silver nanoparticles during pregnancy induces particle size and vehicle dependent changes in vascular tissue contractility in sprague dawley rats. Reprod. Toxicol. 2018, 75 , 10-22. [CrossRef] [PubMed] 
5. Veisi, H.; Azizi, S.; Mohammadi, P. Green synthesis of the silver nanoparticles mediated by thymbra spicata extract and its application as a heterogeneous and recyclable nanocatalyst for catalytic reduction of a variety of dyes in water. J. Clean. Prod. 2018, 170, 1536-1543. [CrossRef]

6. Filipak Neto, F.; Cardoso da Silva, L.; Liebel, S.; Voigt, C.L.; Oliveira Ribeiro, C.A.D. Responses of human hepatoma HepG2 cells to silver nanoparticles and polycyclic aromatic hydrocarbons. Toxicol. Mech. Methods 2017, 28, 69-78. [CrossRef] [PubMed]

7. Pansara, C.; Chan, W.Y.; Parikh, A.; Trott, D.J.; Mehta, T.; Mishra, R.; Garg, S. Formulation optimization of chitosan-stabilized silver nanoparticles using in vitro antimicrobial assay. J. Pharm. Sci. 2019, 108, 1007-1016. [CrossRef] [PubMed]

8. Sukhanova, A.; Bozrova, S.; Sokolov, P.; Berestovoy, M.; Karaulov, A.; Nabiev, I. Dependence of nanoparticle toxicity on their physical and chemical properties. Nanoscale Res. Lett. 2018, 13, 44. [CrossRef]

9. Eklöf, J.; Gschneidtner, T.; Lara-Avila, S.; Nygård, K.; Moth-Poulsen, K. Controlling deposition of nanoparticles by tuning surface charge of $\mathrm{SiO}_{2}$ by surface modifications. RSC Adv. 2016, 6, 104246-104253. [CrossRef]

10. Perelshtein, I.; Lipovsky, A.; Perkas, N.; Tzanov, T.; Gedanken, A. Sonochemical co-deposition of antibacterial nanoparticles and dyes on textiles. Beilstein J. Nanotechnol. 2016, 7,1-8. [CrossRef]

11. Parham, S.; Nemati, M.; Sadir, S.; Bagherbaigi, S.; Wicaksono, D.H.B.; Nur, H. In situ synthesis of silver nanoparticles for Ag-NP/cotton nanocomposite and its bactericidal effect. J. Chin. Chem. Soc. 2017, 64, 1286-1293. [CrossRef]

12. Badawy, A.M.E.; Luxton, T.P.; Silva, R.G.; Scheckel, K.G.; Suidan, M.T.; Tolaymat, T.M. Impact of environmental conditions ( $\mathrm{pH}$, ionic strength, and electrolyte type) on the surface charge and aggregation of silver nanoparticles suspensions. Environ. Sci. Technol. 2010, 44, 1260-1266. [CrossRef] [PubMed]

13. El-Zahry, M.R. A comparative study of sterically and electro-statically stabilized silver nanoparticles for the determination of muscle relaxant tizanidine: Insights of localized surface plasmon resonance, surface enhanced raman spectroscopy and electrocatalytic activity. Talanta 2018, 186, 229-237. [CrossRef] [PubMed]

14. Pal, S.; Tak, Y.K.; Song, J.M. Does the antibacterial activity of silver nanoparticles depend on the shape of the nanoparticle? A study of the gram-negative bacterium escherichia coli. Appl. Environ. Microbiol. 2007, 73, 1712-1720. [CrossRef] [PubMed]

15. Nikiforov, A.; Deng, X.; Xiong, Q.; Cvelbar, U.; DeGeyter, N.; Morent, R.; Leys, C. Non-thermal plasma technology for the development of antimicrobial surfaces: A review. J. Phys. D Appl. Phys. 2016, 49, 204002. [CrossRef]

16. Petlin, D.G.; Tverdokhlebov, S.I.; Anissimov, Y.G. Plasma treatment as an efficient tool for controlled drug release from polymeric materials: A review. J. Control. Release 2017, 266, 57-74. [CrossRef] [PubMed]

17. Zille, A.; Oliveira, F.R.; Souto, A.P. Plasma treatment in textile industry. Plasma Process. Polym. 2015, 12, 98-131. [CrossRef]

18. Gorjanc, M.; Gorensek, M.; Jovancic, P.; Mozetic, M. Multifunctional textiles-Modification by plasma, dyeing and nanoparticles. In Eco-Friendly Textile Dyeing and Finishing; InTech Open: London, UK, 2013.

19. Szulc, J.; Urbaniak-Domagała, W.; Machnowski, W.; Wrzosek, H.; Łacka, K.; Gutarowska, B. Low temperature plasma for textiles disinfection. Int. Biodeterior. Biodegrad. 2018, 131, 97-106. [CrossRef]

20. Tseng, K.-H.; Chou, C.-J.; Liu, T.-C.; Tien, D.-C.; Wu, T.-C.; Stobinski, L. Interactive relationship between silver ions and silver nanoparticles with PVA prepared by the submerged arc discharge method. Adv. Mater. Sci. Eng. 2018, 2018, 1-9. [CrossRef]

21. Kim, H.Y.; Kang, S.K.; Kwon, H.C.; Lee, H.W.; Lee, J.K. Gas temperature effect on reactive species generation from the atmospheric pressure air plasma. Plasma Process. Polym. 2013, 10, 686-697. [CrossRef]

22. Napartovich, A.P. Overview of atmospheric pressure discharges producing nonthermal plasma. Plasma Polym. 2001, 6, 1-14. [CrossRef]

23. ISO 15797:2017 Textiles-Industrial Washing and Finishing Procedures for Testing of Workwear; ISO-International Organization for Standardization: Geneve, Swiss, 2017.

24. ASTM E2149-01 Standard Test Method for Determining the Antimicrobial Activity of Immobilized Antimicrobial Agents Under Dynamic Contact Conditions; ASTM International: West Conshohocken, PA, USA, 2001. 
25. Ma, Y.; Zhou, T.; Su, G.; Li, Y.; Zhang, A. Understanding the crystallization behavior of polyamide 6/polyamide 66 alloys from the perspective of hydrogen bonds: Projection moving-window 2D correlation ftir spectroscopy and the enthalpy. RSC Adv. 2016, 6, 87405-87415. [CrossRef]

26. Zille, A.; Fernandes, M.M.; Francesko, A.; Tzanov, T.; Fernandes, M.; Oliveira, F.R.; Almeida, L.; Amorim, T.; Carneiro, N.; Esteves, M.F.; et al. Size and aging effects on antimicrobial efficiency of silver nanoparticles coated on polyamide fabrics activated by atmospheric DBD plasma. ACS Appl. Mater. Interfaces 2015, 7, 13731-13744. [CrossRef] [PubMed]

27. Khorshidi, B.; Thundat, T.; Fleck, B.A.; Sadrzadeh, M. A novel approach toward fabrication of high performance thin film composite polyamide membranes. Sci. Rep. 2016, 6, 22069. [CrossRef] [PubMed]

28. Menchaca, C.; Alvarez-Castillo, A.; Martinez-Barrera, G.; Lopez-Valdivia, H.; Carrasco, H.; Castano, V.M. Mechanisms for the modification of nylon 6,12 by gamma irradiation. Int. J. Mater. Prod. Technol. 2003, 19, 521-529. [CrossRef]

29. Navarro-Pardo, F.; Martínez-Barrera, G.; Martínez-Hernández, A.; Castaño, V.; Rivera-Armenta, J.; Medellín-Rodríguez, F.; Velasco-Santos, C. Effects on the thermo-mechanical and crystallinity properties of nylon 6,6 electrospun fibres reinforced with one dimensional (1D) and two dimensional (2D) carbon. Materials 2013, 6, 3494-3513. [CrossRef] [PubMed]

30. Montazer, M.; Shamei, A.; Alimohammadi, F. Synthesis of nanosilver on polyamide fabric using silver/ammonia complex. Mater. Sci. Eng. C 2014, 38, 170-176. [CrossRef] [PubMed]

31. Oliveira, F.R.; Zille, A.; Souto, A.P. Dyeing mechanism and optimization of polyamide 6,6 functionalized with double barrier discharge (DBD) plasma in air. Appl. Surf. Sci. 2014, 293, 177-186. [CrossRef]

32. Son, Y.-A.; Sun, G. Durable antimicrobial nylon 66 fabrics: Ionic interactions with quaternary ammonium salts. J. Appl. Polym. Sci. 2003, 90, 2194-2199. [CrossRef]

33. Zhang, B.; Xu, P.; Qiu, Y.; Yu, Q.; Ma, J.; Wu, H.; Luo, G.; Xu, M.; Yao, H. Increasing oxygen functional groups of activated carbon with non-thermal plasma to enhance mercury removal efficiency for flue gases. Chem. Eng. J. 2015, 263, 1-8. [CrossRef]

34. Pamreddy, A.; Skácelová, D.; Haničinec, M.; St’ahel, P.; Stupavská, M.; Černák, M.; Havel, J. Plasma cleaning and activation of silicon surface in dielectric coplanar surface barrier discharge. Surf. Coat. Technol. 2013, 236, 326-331. [CrossRef]

35. Boroumand, M.N.; Montazer, M.; Simon, F.; Liesiene, J.; Šaponjic, Z.; Dutschk, V. Novel method for synthesis of silver nanoparticles and their application on wool. Appl. Surf. Sci. 2015, 346, 477-483. [CrossRef]

36. Zhu, L.; Wang, C.; Qiu, Y. Influence of the amount of absorbed moisture in nylon fibers on atmospheric pressure plasma processing. Surf. Coat. Technol. 2007, 201, 7453-7461. [CrossRef]

37. Zhou, Q.; Wang, K.; Loo, L.S. Investigation of surface properties of plasma-modified polyamide 6 and polyamide 6/layered silicate nanocomposites. J. Mater. Sci. 2010, 46, 3084-3093. [CrossRef]

38. Upadhyay, D.J.; Cui, N.-Y.; Anderson, C.A.; Brown, N.M.D. A comparative study of the surface activation of polyamides using an air dielectric barrier discharge. Colloids Surf. A Physicochem. Eng. Asp. 2004, 248, 47-56. [CrossRef]

39. Zanna, S.; Saulou, C.; Mercier-Bonin, M.; Despax, B.; Raynaud, P.; Seyeux, A.; Marcus, P. Ageing of plasma-mediated coatings with embedded silver nanoparticles on stainless steel: An XPS and ToF-SIMS investigation. Appl. Surf. Sci. 2010, 256, 6499-6505. [CrossRef]

40. Wang, X.; Somsen, C.; Grundmeier, G. Ageing of thin Ag/fluorocarbon plasma polymer nanocomposite films exposed to water-based electrolytes. Acta Mater. 2008, 56, 762-773. [CrossRef]

41. Liu, W.; Li, B.; Cao, R.; Jiang, Z.; Yu, S.; Liu, G.; Wu, H. Enhanced pervaporation performance of poly (dimethyl siloxane) membrane by incorporating titania microspheres with high silver ion loading. J. Membr. Sci. 2011, 378, 382-392. [CrossRef]

42. Itani, H.; Keil, P.; Lützenkirchen-Hecht, D.; Haake, U.; Bongard, H.; Dreier, A.; Lehmann, C.W.; Grundmeier, G. XANES studies of the formation of Ag-nanoparticles in LBL deposited polyelectrolyte thin films. Surf. Coat. Technol. 2010, 205, 2113-2119. [CrossRef]

43. Vu, N.K.; Zille, A.; Oliveira, F.R.; Carneiro, N.; Souto, A.P. Effect of particle size on silver nanoparticle deposition onto dielectric barrier discharge (DBD) plasma functionalized polyamide fabric. Plasma Process. Polym. 2013, 10, 285-296. [CrossRef] 
44. Navarro Gallón, S.M.; Alpaslan, E.; Wang, M.; Larese-Casanova, P.; Londoño, M.E.; Atehortúa, L.; Pavón, J.J.; Webster, T.J. Characterization and study of the antibacterial mechanisms of silver nanoparticles prepared with microalgal exopolysaccharides. Mater. Sci. Eng. C 2019, 99, 685-695. [CrossRef] [PubMed]

45. Benn, T.M.; Westerhoff, P. Nanoparticle silver released into water from commercially available sock fabrics. Environ. Sci. Technol. 2008, 42, 4133-4139. [CrossRef] [PubMed]

46. Kulthong, K.; Srisung, S.; Boonpavanitchakul, K.; Kangwansupamonkon, W.; Maniratanachote, R. Determination of silver nanoparticle release from antibacterial fabrics into artificial sweat. Part. Fibre Toxicol. 2010, 7, 8. [CrossRef] [PubMed]

(C) 2019 by the authors. Licensee MDPI, Basel, Switzerland. This article is an open access article distributed under the terms and conditions of the Creative Commons Attribution (CC BY) license (http://creativecommons.org/licenses/by/4.0/). 